\title{
The measurement of intellectual capital by market capitalization method: Empirical study of Polish listed companies
}

Salome Svanadze, Ilia State University, Tbilisi, The Republic of Georgia (EU affiliation) salome.svanadze.1@iliauni.edu.ge

Magdalena Kowalewska, Warsaw University of Life Sciences, Warsaw, Poland magdalena kowalewska@sggw.pl

\begin{abstract}
Intellectual capital has become a fundamental source for enterprises, but its measurement and reporting remain a major challenge for managers and researchers. The purpose of this paper is to examine and report the differences in the Intellectual Capital (IC) Market Value (MV) to Book Value $(B V)$ of the Polish WIG 20 indexed companies from Warsaw Stock Exchange. The data necessary to perform the calculations in accordance with the MV/PV method came from the financial statements for the period 2010-2014 of 20 Polish companies. The MV/BV method provides the means to measure intellectual capital in a precise and timely calculation and is particularly useful for the companies that are listed on the stock market. Results are presented and followed by discussion and implication for future research.
\end{abstract}

Keywords: intellectual capital, market capitalization method (MV/BV), WIG20 companies

\section{Introduction}

Intellectual Capital (IC) has gradually become an essential part of running a successful business, but defining it remains a challenging task (Edvinsson and Malone, 1997). IC has been defined in a number of ways. According to Gutherie (2001), the concept of IC is used, for example, to reflect the verifiable value of the company beyond its book value (BV). Svanadze and Kowalewska (2015) stated that organizations are motivated to measure their IC to assist with competitive benchmarking and to provide structured information to the capital and labor markets to enhance perceptions of the company. However, as IC is different from the traditional capital in accounting terms and managers often struggle to evaluate the value of IC as appropriately as possible (Tai \& Chen, 2009). Marr and Schiuma (2001) defined IC as knowledge assets that are attributed to the improved competitive position of an organization. Most of the IC classifications and definitions are adaptations of the ones proposed by Sveiby Knowledge Associate (available at http://www.sveiby.com/), Stewart (1997), as well as Edvinsson and Malone (1997). These scholars suggested different levels of aggregation of IC components, except for Lev (2001) who interpreted intangible assets as the rights to future benefits having no physical or financial forms (Sydler, 2013). Sydler (2013) argued that IC is a source of long-term sustainable profits that creates a competitive advantage for organizations. 
This article aims to examine and report the differences in the IC Market Value (MV) to Book Value (BV) of the Polish WIG 20 indexed companies from Warsaw Stock Exchange. The WIG 20 is a capitalization-weighted stock market index of the 20 largest companies on the Warsaw Stock Exchange (www.gpw.pl). Consistent with its aim, this study states the following research question:

RQ1: Are there differences in the extent of the intellectual capital (MV/BV) index of WIG 20 companies (if any)?

To answer the research question, first, the analyses of the term "intellectual capital" including models and reporting are made followed by the MV/BV description details and its applicability to the WIG 20 company data. The above enabled us to present conclusions on this matter below.

\section{Analysis of definition and models of IC - MV/BV calculation method}

The most known classification of measurement methods of intellectual capital related to the division are outlined by Sveiby Knowledge Associate (available at http://www.sveiby.com/). These classifications are grouped in the following:

1. Direct Intellectual Capital Methods (DICM) - focusing on studying particular intangibles. The methods included in this group are: The Value Explorer, Intangible Assets Valuation, Accounting for the Future, Inclusive Valuation Methodology, Total Value Creation, and Technology Broker.

2. Market Capitalization Methods (MCM) - that arrives at the value of intellectual capital from the difference between market value and the book value. MCM includes Ratio of market value to book value (MV/BV), Tobin's Q, and Investor Assigned Market Value.

3. Return on Assets Method (ROA) - examines the profitability of induvial assets involved in the company. ROA includes Value Added Intellectual Coefficient, Calculated Intangible Value, Human Resources Costing, Knowledge Capital Earnings, and Economic Value Added (EVA).

4. Scorecard Methods (SC) - similarly to direct measurement methods focus on individual components that rarely allow for verification of their induvial value added. SC includes Balanced Scorecard, Intangible Assets Monitor, IC-Rating, Skandia Navigator, and Holistic Approach Value.

For the purposes of this research, we focused on IC measurement method of market-to-book value ratio (MV/BV) that was originally proposed by Stewart (1997). According to Gutherie (2001), $\mathrm{MV} / \mathrm{BV}$ is the ratio of each company that is often used as an indication that a company holds significant share IC that is not reflected in its financial statements. MV/BV can be used as a tool for market analysts as well as investors to identify under or overvalued companies. Maverick (2015) states that any MV/BV value below 1.0 is considered a good value, signifying a conceivably undervalued stock. Nonetheless, some investors consider stocks with a MV/BV value below 3.0 acceptable.

For the purpose of the present study, the following formula will be used to calculate: 


\author{
MV/BV=Market Value/Book Value \\ where Market Value $=$ Price of Shares x Number of Shares \\ and Book Value $=$ Assets - Debt Capital
}

According to Chen (2005), management capability in running the company's financial resources depends on the value creation process, the measure of which is the firm's profitability proxied by a Return-On-Equity (ROE) index, as control variables. Similar to other IC calculation methods, e.g., Value-added Intellectual Coefficient (VAIC) has been mostly questioned because it is resulting from financial statements (Maditinos et al., 2011). According to Saenz (2005), economists have noticed a growing gap between the MV of companies' shares and their BV. The gap suggests the inadequacy of the traditional accounting that can be explained by IC assets not recognized in company's balance sheets (Brennan \& Connell, 2000).

Alternatively, Lipunga (2014) suggested that market-to-book value ratio method confirmed that IC was a significant part of the total value of the listed companies of Malawi Stock Exchange. It is also pronounced that there is no one method that is credible enough (Jurczak, 2008) as they are all developing. Moreover, according to Brennan (2001), the difference between market value and book value cannot be wholly attributed to intellectual assets as parts of it may relate to unlikely tangible asset values that appear on the organization's balance sheet. MV/BV has been criticized as it allows the volatility of the market price of equity to be a factor. However, according to Urbanek (2008) and Godun (2013), market capitalization method is one of the most useful options to weigh IC among other methods considering the ease of the calculation with data availability.

The MV/BV is easier to calculate than VAIC, but it also has its disadvantages. The most serious disadvantage is that it includes the market value (on a specific date, which is variable) in the calculation, and is affected by external factors. Therefore, changes in the area of the whole economy can significantly affect the value of companies, causing overestimation or underestimation of the value of intellectual capital. Surely, MV/BV ratio is particularly useful for companies listed on the stock market. For other companies, the problem may be the estimation of the market value.

\title{
The Polish WIG 20 Indexed Companies
}

In this section, the introductory information about the Polish WIG 20 indexed companies and their industry sectors are provided. It is a price index and, thus, when it is calculated it accounts only for prices of underlying shares whereas dividend income is excluded (Svanadze \& Kowalewska, 2015). The WIG20 indexed companies may not include more than five companies from a single exchange sector.

1. ASSECOPOL - is the largest information technology (IT) company listed on the Warsaw Stock Exchange. It has developed technologically advanced software solutions for all key sectors of the economy for more than 20 years.

2. ALIOR - markets itself as a universal bank that addresses services to both individual and businesses customers. 
3. BZWBK - Bank Zachodni S.A. was a Poland-based commercial bank that offered the normal range of retail and commercial banking services. Its owners, Allied Irish Banks, merged it with Wielkopolski Bank Kredytowy in 2001 to form BZ-WBK.

4. CCC S.A. - is the largest footwear retailer in Central Europe and the biggest footwear manufacturer in Europe. At the end of 2015, the CCC Group comprises 773 stores in 16 countries. During the year, CCC sells over 28 million pairs of shoes. Within one year, the company offers nearly five thousand models of shoes. The company owns, in total, more than 67 registered brands of goods of footwear.

5. CYFROWY POLSAT - is a Polish DTH platform. It was launched on December 5, 1999, and is owned by Cyfrowy Polsat S.A. It is the fourth largest digital platform in Europe and the largest in Central and Eastern Europe. Cyfrowy Polsat has 3.47 million subscribers.

6. ENEA - the largest energy groups in Poland that produce electricity, transmits and sells it to homes and businesses. Company transmission lines are located in north - western part of the country. The power plant produces energy in Kozienice, $75 \mathrm{~km}$ from Warsaw. It is headquartered in Poznan, employing over 10,000 people and selling electricity to 2.4 million customers, including individual consumers, small and medium-sized companies, as well as large industrial plants.

7. ENERGA- core business entails distribution, generation, and sales of electricity and heat. Energa is one of the three largest electricity suppliers in Poland, that supply electricity to more than 2.9 million retail and business clients and operates in more than 184 thousand $\mathrm{km}$ of power lines for the transmission of $21.5 \mathrm{TWh}$ of electricity annually. Company's distribution grid covers almost $75 \mathrm{~K} \mathrm{~km}^{2}$, i.e. representing approximately $24 \%$ of the country's landmass.

8. EUROCASH - Eurocash Group is a leading wholesale distributor of fast moving consumer goods (FMCG) in Poland. Eurocash cash\&carry and franchise store chains spread all over the country.

9. KGHM POLSKA - KGHM runs technologically advanced exploration and smelting activities. The company owns assets located on three continents. It focuses on the extraction of ores, production of copper and other non-ferrous metals.

10. LPP - is a company engaged in the design and distribution of clothing in Poland and abroad (countries of Central Europe, Eastern Europe, Western Balkans \& the Middle East). Clothing designs are prepared in design offices located in the company's headquarters in Gdansk and in Krakow, and their production is outsourced to contractors in Asia, Turkey, and Poland.

11. MBANK - mBank has been a synonym for innovative banking solutions for years. It was the first fully Internet-based bank in Poland and today continues to set the direction of the mobile and online banking development. MBank is one of the strongest and fastest growing financial brands in Poland, listed on the Warsaw Stock Exchange for 23 years now.

12. ORANGE - former Telekomunikacja Polska is a Polish telecommunications provider established in December 1991. It is a public company traded on the Warsaw Stock Exchange, with a controlling stake owned by Orange S.A., the latter controlling over 50\% of this stake by 2002. It operates the following services: PSTN, ISDN, GSM 900/1800 network, ADSL, IDSL, Frame Relay, ATM, and Inmarsat 
13. BANK PKO - is one of the largest financial institutions in Poland, and it is also one of the leading financial groups in Central and Eastern Europe, remains as the undisputed leader of the Polish banking sector, both in terms of scale of operations, as well as equity, assets, number of customers and the extent of the distribution network

14. PGE - The PGE Capital Group is Poland's largest energy sector company with respect to sales revenues and net profit. Thanks to the combination of its own fuel resources, power generation, and distribution networks, PGE guarantees a safe and reliable power supply to over 5 million households, businesses, and institutions.

15. PGNIG - is the leader of the Polish natural gas market. The company's core business includes exploration and production of natural gas and crude oil fields and, through its key subsidiaries, import, storage, sale and distribution of gaseous and liquid fuels, as well as the generation of heat and electricity. PGNiG SA has a stake in approximately 30 companies, including entities providing professional geophysical, drilling and maintenance services, highly esteemed on international markets.

16. PKNORLEN - Rankings recently published by the British financial magazine Euromoney show PKN ORLEN as being the best-managed oil company in the region. PKN ORLEN has also been named the most valuable Polish brand and the best employer.

17. PKOBP - a strong and modern universal bank that combines traditionally dominant role in the retail sector with the gradual strengthening of the market position of the corporate and investment segments

18. PZU - is a leader in the insurance market and one of the largest financial institutions in Poland. It is also one of the top insurance groups in Central and Eastern Europe. The main advantages of the Group concern the strong competitive position, high level of equity and high effectiveness of the business activity. PZU Group offers the largest selection of insurance products on the Polish market (nearly 200 insurance products) and constantly enhances the scope of provided services. The activity of PZU group encompasses the comprehensive insurance-financial service. The Group entities provide services in the area of non-life insurance, personal and life insurance, investments funds, and open pension fund.

19. SYNTHOS S.A. - is one of the largest manufacturers of chemical raw materials in Poland. The company is the third European manufacturer of expandable emulsion rubber and a leading European manufacturer of polystyrene.

20. TAURON - TAURON Polska Energia S.A. is the mother company in the TAURON Group - one of the largest business entities in Poland, with approximately PLN 16 billion equity and approximately 25 thousand employees. Core businesses of the TAURON Group include hard coal mining, generation, distribution and supply of electricity and heat. The TAURON Group supplies over 49 TWh of electricity to over 5.4 million customers per year. This makes the company the largest distributor of electricity in Poland. The holding controls approximately $29 \%$ of Polish hard coal resources.

Because of incomplete data from the company, Kernel, was excluded from the study. WIG20 index value has changed compared to the previous year. Companies: Bogdanka, Lotos, Kernel, and JSW have been changed to Cyfrowy Polsat, CCC, Energa, and Enea.

Secondary data needed to measure intellectual capital derived from the financial statements for the years 2010-2014 published on the official websites of the companies. 
Data necessary to perform the calculations in accordance with the MV/BV method came from balance sheets, and profit and loss account for the period 2010-2014. The market value was calculated by dividing the number of shares and value of trading at the beginning of next year. The book value was calculated as the difference between total assets and total liabilities.

\section{Results}

The MV/BV index represents the relationship between the MV and the BV. Table 1 shows the intellectual capital (MV/BV) index from 2010 to 2014 for the 20 researched companies. As can be noted, the companies ALIOR and ENERGA did not include data for all five years. ALIOR was missing the data for 2010 and ENERGA was missing the data for three years, 2010, 2011, and 2013.

Table 1. Intellectual capital index (MV/BV) for researched companies

\begin{tabular}{|l|r|r|r|r|r|}
\hline & Y2010 & Y2011 & Y2012 & Y2013 & Y2014 \\
\hline ASSECOPOL & 1.02 & 0.85 & 0.79 & 0.78 & 0.85 \\
\hline ALIOR & - & 0.45 & 2.02 & 2.37 & 1.81 \\
\hline BZWBK & 2.31 & 0.71 & 2.15 & 2.64 & 2.05 \\
\hline CCC & 7.54 & 4.84 & 7.81 & 11.26 & 11.30 \\
\hline CYFROWY POLSAT & 0.01 & 2.50 & 2.32 & 2.31 & 1.67 \\
\hline ENEA & 1.04 & 0.74 & 0.62 & 0.55 & 0.59 \\
\hline ENERGA & - & - & - & 1.09 & 1.53 \\
\hline EUROCASH & 12.09 & 11.26 & 12.66 & 14.56 & 6.70 \\
\hline KGHM POLSKA & 2.36 & 0.96 & 1.73 & 1.02 & 0.90 \\
\hline LPP & 5.02 & 3.92 & 6.78 & 11.16 & 8.43 \\
\hline MBANK & 1.83 & 1.28 & 1.43 & 2.03 & 1.90 \\
\hline ORANGE & 0.52 & 0.54 & 0.41 & 0.31 & 0.27 \\
\hline BANK PKO & 2.42 & 1.78 & 1.93 & 2.09 & 2.04 \\
\hline PGE & 1.54 & 1.22 & 1.16 & 1.02 & 1.07 \\
\hline PGNIG & 0.87 & 1.02 & 1.13 & 1.08 & 0.87 \\
\hline PKNORLEN & 1.04 & 0.70 & 0.92 & 0.65 & 1.03 \\
\hline PKOBP & 2.58 & 1.76 & 1.87 & 1.99 & 1.62 \\
\hline PZU & 2.44 & 2.07 & 2.64 & 3.01 & 3.19 \\
\hline SYNTHOS & 3.71 & 5.94 & 6.65 & 11.47 & 4.78 \\
\hline TAURON & 0.64 & 0.54 & 0.47 & 0.40 & 0.43 \\
\hline
\end{tabular}

In 2010, only 3 of the 20 companies had IC index (MV/BV) value ratio below 1 . They were ORANGE, TAURON, PGNIG. In 2011, the number of companies with IC index (MV/BV) value ratio below 1 increased to 8 out of 20. These companies were ALIOR, ORANGE, TAURON, PKNORLEN, BZWBK, ENEA, ASSECOPOL, and KGHM POLSKA.

In 2012 and 2103, ORANGE, TAURON, PKNORLEN, ENEA, ASSECOPOL were the only five companies with IC index (MV/BV) value ratio below 1. In 2014, 6 of the 20 companies had IC index (MV/BV) value ratio below 1. They were ORANGE, TAURON, ENEA, ASSECOPOL, PGNIG, and KGHM POLSKA. 
Table 2 shows the five-year average of IC index (MV/BV) value ratio for all 20 companies. As can be seen, there were only six companies out of 20 companies that had IC index (MV/BV) value ratio below 1. These companies are ORANGE (0.41), TAURON (0.50), ENEA (0.71), ASSECOPOL (0.86), PKNORLEN (0.87), and PGNIG (0.99).

Fourteen of the 20 companies had IC index (MV/BV) value ratio above 1. These companies were PGE, ENERGA, KGHM POLSKA. ALIOR. MBANK, CYFROWY POLSAT, PKOBP, BZWBK, BANK PKO, PZU, SYNTHOS, LPP, CCC, and EUROCASH. The last four companies had the largest IC index (MV/BV) value ratio starting from above 6 to above 11 (See Table 2).

Table 2. Five-year average of IC index (MV/BV) for all 20 companies (in descending order)

\begin{tabular}{|l|r|r|r|r|r|r|}
\hline & Y2010 & Y2011 & Y2012 & Y2013 & Y2014 & Average \\
\hline ORANGE & 0.52 & 0.54 & 0.41 & 0.31 & 0.27 & 0.41 \\
\hline TAURON & 0.64 & 0.54 & 0.47 & 0.40 & 0.43 & 0.50 \\
\hline ENEA & 1.04 & 0.74 & 0.62 & 0.55 & 0.59 & 0.71 \\
\hline ASSECOPOL & 1.02 & 0.85 & 0.79 & 0.78 & 0.85 & 0.86 \\
\hline PKNORLEN & 1.04 & 0.70 & 0.92 & 0.65 & 1.03 & 0.87 \\
\hline PGNIG & 0.87 & 1.02 & 1.13 & 1.08 & 0.87 & 0.99 \\
\hline PGE & 1.54 & 1.22 & 1.16 & 1.02 & 1.07 & 1.20 \\
\hline ENERGA & - & - & - & 1.09 & 1.53 & 1.31 \\
\hline KGHM POLSKA & 2.36 & 0.96 & 1.73 & 1.02 & 0.90 & 1.39 \\
\hline ALIOR & - & 0.45 & 2.02 & 2.37 & 1.81 & 1.66 \\
\hline MBANK & 1.83 & 1.28 & 1.43 & 2.03 & 1.90 & 1.69 \\
\hline CYFROWY POLSAT & 0.01 & 2.50 & 2.32 & 2.31 & 1.67 & 1.76 \\
\hline PKOBP & 2.58 & 1.76 & 1.87 & 1.99 & 1.62 & 1.96 \\
\hline BZWBK & 2.31 & 0.71 & 2.15 & 2.64 & 2.05 & 1.97 \\
\hline BANK PKO & 2.42 & 1.78 & 1.93 & 2.09 & 2.04 & 2.05 \\
\hline PZU & 2.44 & 2.07 & 2.64 & 3.01 & 3.19 & 2.67 \\
\hline SYNTHOS & 3.71 & 5.94 & 6.65 & 11.47 & 4.78 & 6.51 \\
\hline LPP & 5.02 & 3.92 & 6.78 & 11.16 & 8.43 & 7.06 \\
\hline CCC & 7.54 & 4.84 & 7.81 & 11.26 & 11.3 & 8.55 \\
\hline EUROCASH & 12.09 & 11.26 & 12.66 & 14.56 & 6.70 & 11.45 \\
\hline
\end{tabular}

\section{Summary and Discussion}

This study was undertaken to examine and report the differences in the IC (MV/BV) of the Polish WIG 20, a capitalization-weighted stock market index of the 20 largest companies on the Warsaw Stock Exchange. The following research question was stated: Are there differences in the extent of the intellectual capital (MV/BV) index of WIG 20 companies (if any)? The research question was answered using the formula -- $\mathrm{MV} / \mathrm{BV}=$ Market Value/Book Value that was originally proposed by Stewart (1997). MV/BV is the ratio of each company, often used as an indication that a company holds significant share IC that is not reflected in its financial statements. Any market-to-book value ratio (MV/BV) under 1.0 is considered a good MV/BV value, since the stock is undervalued (Gutherie, 2001). 
Results of the study from 2010 to 2014 for the 20 companies showed only three companies in 2010 with (MV/BV) ratio under 1.0. In 2011, this number increased to 8 companies. Only 5 of the 20 companies produced (MV/BV) ratio under 1.0 in 2012 and 2013. Six of the 20 companies in 2014 had IC index (MV/BV) value ratio below 1.

A five-year average of IC index (MV/BV) value ratio results for all 20 companies indicated that 6 companies out of 20 companies had IC index (MV/BV) value ratio below 1. The IC index (MV/BV) value ratio for the rest of the 14 was above 1 . These results show a trend for the value of these companies for investors' decision-making on buying or selling stocks. These results can be used as a critical element of any attempt for investors in analyzing WIG 20 companies for investment. For example, a value-seeking investor who trades for an (MV/BV) value ratio value less than 1 implies that market value of the stock is less than the company's stated book value. These results can be used to identify low-priced stocks in the Polish WIG 20 which have potential high-growth prospects.

From the results of this study; one can ascertain that there are companies from WIG 20 that have the significant IC, possibly making them successful in business. Still, this information is not included in the annual financial statements and constitutes a curiosity rather than an important competitive factor. The MV/BV method certainly shows to be very useful for ongoing monitoring of the intellectual capital of the company. The method also allows capturing the different levels of IC of the WIG 20 companies, thus answering the present study's research question. However, a limitation to the $(\mathrm{MV} / \mathrm{BV})$ value ratio less than 1 may also be interpreted that the stock is undervalued. Equally, a stock with the (MV/BV) value ratio greater than 1 can be constructed as being overvalued or pricey. Although $(\mathrm{MV} / \mathrm{BV})$ value ratio is a critical element in determining to invest in a company, it is not the only approach investors should rely upon. Investors should also keep in mind that ratios (beyond the scope of this paper) such as price to earnings, price to sales, and debt to equity may be other approaches to sound investment decision.

It should be noted that empirical material used in this paper has its limitations. The limitations are short-term data and the analysis of companies from different sectors and calculation of market value. Further studies may include companies that are not listed on the stock market with a wider sample size.

\section{References}

Brennan N. (2001). Reporting intellectual capital in annual reports: Evidence from Ireland. Accounting, Auditing \& Accountability Journal, 14(4), 423-436

Brennan N., \& Connell B. (2000). Intellectual capital: Current issues and policy implications. Journal of Intellectual Capital, 1 (3), 206-240

Chen, M. C., Cheng, S. J., \& Hwang, Y. (2005). An empirical investigation of the relationship between intellectual capital and firms' market value and financial performance. Journal of Intellectual Capital, 6(2), 159-176.

Edvinsson, L., \& Malone, M.S. (1997). Intellectual capital: Realizing your company's true value by finding its hidden brainpower. Harper Business. New York, N.Y. 
Godun, J. (2013). Intellectual capital valuation and stock market performance in an era of financial turmoil. Club of Economics in Miskolc, 9(2), 53-61

Gutherie, J (2001). The management, measurement, and the reporting of intellectual capital, Journal of Intellectual Capital, 2(1), 27-41.

Jurczak, J. (2008). Intellectual capital measurement, methods. Economics and organisation of enterprise, 1(1), 37-45

Lev, B. (2001) Intangibles: Managment, measurement, and reporting. New York, NY: Brookings Institution Press.

Lipunga, A. (2014). A longitudinal assessment of intellectual capital of companies listed in Malawi stock exchange. European Journal of Business and Management, 6(9), 27-35

Maar, B., \& Schiuma, G. (2001). Measuring and managing intellectual capital and knowledge assets in new economy organizations. Handbook of performance measurement.

Maditinos, D., Chatzoudes, D., Tsairidis, C., \& Theriou, G. (2011). The impact of intellectual capital on firms' market value and financial performance. Journal of Intellectual Capital, 12(1), 132-51.

Maverick, J. B. (2015). What is considered a good price to book ratio? Available at http://www.investopedia.com/ask/answers/010915/what-considered-good-price-bookratio.asp

Saenz, J. (2005). Human capital indicators, business performance and market-to-book ratio. Journal of Intellectual Capital, 6 (3), 374-384

Steward, T. A. (1997). Intellectual capital: The new wealth of organizations, Dell Publishing Group.

Svanadze, S., \& Kowalewska, M. (2015). The measurement of intellectual capital by VAIC method - example of WIG 20. Online Journal of Applied Knowledge Management, 3(2), $36-44$

Sydler, R., Haefligerb, S., \& Pruksac, R. (2013). Measuring intellectual capital with financials figures: Can we predict firm profitability? European Management Journal 1(8), 1-16.

Tai, W. S., \& Chen, C. T. (2009). A new evaluation model for intellectual capital based on computing with linguistic variables, Expert System with Applications, 36, 3483.

Urbanek, G. (2008). Valuation of company’s intangible assets. PWE, Warsaw.

Urbanek, G. (2016). The links between the intellectual capital efficiency ratio (ICER) and the performance of Polish listed companies from the food industry sector. Electronic Journal of Knowledge Management, 14(4), 220-230.

\section{Authors' Biographies}

Salome Svanadze has a B.Sc. degree in the field of Management and Economics and holds a M.Sc. in Economics from the Faculty of Economics, Georgian State University. She is currently 
working on her Ph.D. in Business Administration at the Faculty of Business at Ilia State University, Georgia after 2 years of study exchange at Warsaw University of Life Sciences. Considering over 5 years of working experience in the Investment Funds at emerging markets, her research and teaching interests consist of intellectual capital, creating economic opportunities (particularly utilizing opportunities at emerging markets) as well as phenomena of knowledge and trust management of leadership in enterprises.

Magdalena D. Kowalewska is a Ph.D. Student at Warsaw University of Life Sciences, Faculty of Economics. Her research field is focused on intellectual capital management, the intellectual capital of the regions, the economic aspect of regional development, human capital management, the human capital of rural areas and knowledge management. She is also a member of international research project Global Knowledge Survey in the field of knowledge management. 